\title{
Splitting of Micrasterias fimbriata (Desmidiales, Viridiplantae) into two monophyletic species and description of Micrasterias compereana sp. nov.
}

\author{
Jiří Neustupa*, Jan Št’astný \& Pavel Škaloud
}

Department of Botany, Faculty of Science, Charles University of Prague, Benatska 2, Prague, 12801, Czech Republic

*Author for correspondence: neustupa@natur.cuni.cz

\begin{abstract}
Background - Micrasterias fimbriata, a conspicuous desmid species, has recently been shown to be composed of two clearly delimited monophyletic clades within the genus Micrasterias, closely related to several other well-defined Micrasterias species (M. brachyptera, M. rotata, M. torreyi). The members of both clades can also be unambiguously recognized by careful morphological analysis. In addition, their distribution areas in Europe and North America are largely vicariant. Interestingly, morphological features of one of the clades do not correspond with any of the previously described infraspecific taxa of M. fimbriata.

Material and methods - The study was based on a combination of morphological and molecular phylogenetic analyses of the clonal strains and natural populations.

Key results and conclusions - In this study, we present formal taxonomic description of Micrasterias compereana for specimens formerly included within traditional M. fimbriata, but differring in their phylogenetic position and discriminative morphological characteristics. Phylogenetic analysis was based on the nuclear $18 \mathrm{~S}$ rDNA and the plastid-encoded $\operatorname{trn} G^{U C C}$ intron sequence data. Morphological differences between species were illustrated by light and scanning electron microscopy. The analysis of natural samples, strains and published records showed that $M$. compereana occurs in North America and western Europe. Conversely, M. fimbriata sensu stricto probably only occurs in temperate and boreal regions of Europe and Asia.
\end{abstract}

Key words - Desmidiales, green algae, Micrasterias, new species, taxonomy, Zygnematophyceae.

\section{INTRODUCTION}

The freshwater microalgal genus Micrasterias C.Agardh ex Ralfs represents a monophyletic lineage of the Desmidiaceae (Škaloud et al. 2011). Besides the species traditionally included in this genus on the basis of the morphological data (see e.g. Prescott et al. 1977, Růžička 1981, Coesel $\&$ Meesters 2007), the Micrasterias lineage also includes several morphologically dissimilar taxa, such as Micrasterias ralfsii (Brébisson ex Ralfs) Škaloud, Nemjová, Veselá, Černá \& Neustupa and M. dickiei (Ralfs) Škaloud, Nemjová, Veselá, Černá \& Neustupa. These species were previously classified into other desmid genera, but proved to be included within the phylogenetically defined genus Micrasterias on the basis of the multigenic molecular data (Gontcharov 2008, Hall et al. 2008, Gontcharov \& Melkonian 2011, Škaloud et al. 2011).

The morphological species concepts within the genus turned out to be relatively well supported by molecular data (Nemjová et al. 2011, Neustupa et al. 2010, 2011). While different populations of individual traditional species, such as
M. rotata, typically formed monophyletic or closely related lineages (Neustupa et al. 2011), the phylogenetic species diversity of several other taxa, such as $M$. truncata Brébisson ex Ralfs, M. crux-melitensis Ralfs, or M. fimbriata Ralfs, proved to be higher than what was expected solely from the morphological data (Nemjová et al. 2011, Neustupa et al. 2010). The infraspecific phylogenetic clades of traditional M. crux-melitensis and M. truncata often could not be unambiguously delimited by morphological methods, and their separate species status remains uncertain. On the contrary, phylogenetic structure of the traditional $M$. fimbriata proved to be considerably less complicated (Neustupa et al. 2011). The natural populations and strains of this species, originating from various European and North American localities, turned out to belong to two well delimited and homogenous phylogenetic lineages on the basis of the group II intron sequences of the plastid encoded $\operatorname{trn} G^{U C C}$ gene. Both lineages were firmly placed into the clade $\mathrm{C}$ of the genus Micrasterias sensu Škaloud et al. (2011). Interestingly, the members of the $M$. fimbriata lineages were clearly morphologically delimited and could be unambiguously recognized, either 
by detailed light microscopy of cells, or by their geometric morphometric analysis. In addition, subsequent analysis of the published M. fimbriata records revealed that geographic distribution of both lineages in Europe and in North America is largely vicariant (Neustupa et al. 2011).

In this study we supplemented the distribution records of both clades from additional European and North American localities. Additional molecular analyses of the combined $18 \mathrm{~S}$ rDNA gene and $\operatorname{trn} G^{U C C}$ intron sequences as well as morphological comparison of strains and natural samples supported the previously suggested taxonomic structure of the clade $\mathrm{C}$ of the genus Micrasterias, including both clades with populations traditionally identified as M. fimbriata. Consequently, this traditional taxon is formally split into two species, with newly described $M$. compereana for specimens differing from the holotype published by Ralfs (1848).

\section{MATERIAL AND METHODS}

Strains of traditionally defined $M$. fimbriata were obtained from three culture collections (CAUP - our own isolates, SVCK, and SAG). They were complemented with material and single-cell isolates from natural populations (electronic appendix 1). The strains for molecular analyses and scanning electron microscopy (SEM) were cultured for eight weeks in $100 \mathrm{~mL}$ Erlenmeyer flasks in liquid DY IV medium (Andersen et al. 2005). They were maintained at temperatures of $22^{\circ} \mathrm{C}$ and illuminated at $40 \mathrm{mmol} \mathrm{m}^{-2} \mathrm{~s}^{-1}$ from $18 \mathrm{~W}$ cool fluorescent tubes (Philips TLD 18W/33). Microphotographs were taken under an Olympus BX51 light microscope with an Olympus Z5060 camera. The samples for SEM were placed on acetone-washed coverslips and dehydrated by an acetone series. Then, they were dried to a critical point with liquid $\mathrm{CO}_{2}$, sputter coated with gold, and examined with a JEOL 6380 LV.

To illustrate the phylogenetic position of both M. fimbriata lineages, we inferred the concatenated phylogeny of SSU rDNA and $\operatorname{trn} G^{U C C}$ intron sequences selected from the DDBJ/EMBL/GenBank databases. The alignment was manually built using MEGA 4 (Kumar et al. 2008), and then optimized using MAFFT, version 6, applying the Q-INS-i strategy (electronic appendix 2). Suitable substitution models for both analyzed genes were selected using jModelTest 2.1.4. This BIC-based model selection procedure selected the TrNef + I model for the SSU rDNA partition, and the TPM1uf + I model for the $\operatorname{trn} G^{U C C}$ partition. The phylogenetic tree was inferred by Bayesian inference (BI) using MrBayes version 3.2.1 (Ronquist \& Huelsenbeck 2003). The analysis was carried out on a partitioned dataset using different substitution models selected using jModelTest 2.1.4. The general structure of each substitution model was determined by 'Iset' command, and the model parameters were set using the prior Dirichlet distributions defining the frequencies of nucleotides (statefreqpr) and nucleotide sbstitution rates (revmatpr). All parameters were unlinked among partitions. Two parallel MCMC runs were carried out for five million generations, each with one cold and three heated chains. Trees and parameters were sampled every 100 generations. Convergence of the two cold chains was assessed during the run by calculating the average standard deviation of split frequen- cies (SDSF). The SDSF value between simultaneous runs was 0.000505 . The burn-in was determined using the 'sump' command. Bootstrap analyses were performed by maximum likelihood (ML) and weighted parsimony (wMP) criteria using GARLI, version 0.951 (Zwickl 2006) and PAUP*, version 4.0b10 (Swofford 2002), respectively. Both analyses were performed as described in Št’astný et al. (2013).

\section{RESULTS AND DISCUSSION}

Micrasterias compereana Neustupa, Št’astný \& Škaloud, sp. nov.

Figs $1 \mathrm{~A}-\mathrm{E} \& 2 \mathrm{~A}-\mathrm{B}$

Type: France, Aquitaine (department no. 40: Landes), oli-

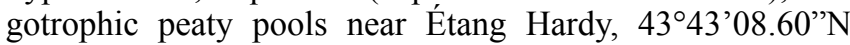
0122'09.42”W, alt. 35 m, 24 May 2011, Neustupa K608 (holo-: PRC). Living strain CAUP K608 (fig. 1A-E, fig. 2AB) and sequences FR852604 (18S rDNA) and FR691070 ( $\operatorname{trn} G^{U C C}$ intron) were acquired from the type material.

Description - Cells in frontal view 185-255 $\mu \mathrm{m}$ long and 170-225 $\mu \mathrm{m}$ broad, circular or broadly elliptical in outline. Sinus deep, closed from isthmus to about two thirds of its length, then gradually opening. Isthmus $25-35 \mu \mathrm{m}$ broad, cell thickness $40-50 \mu \mathrm{m}$. Polar lobes gradually broadening towards apex, which is $45-60 \mu \mathrm{m}$ broad. Apex with four emergent subapical spines. Apical edges bidentate, gradually tapered to acute projections, often eyelash-like bended. Incisions between polar and lateral lobes narrow, usually more than half of the semicell length. Lateral lobes incised to lobules of the $3^{\text {rd }}$ or $4^{\text {th }}$ order. First order lateral lobules asymmetric; the lower lobule distinctly narrower. Terminal lobules gradually tapered toward the apices, terminated by acute projections. Rows of minute spines usually present along sinus and major incisions. Differing from other taxa of the genus Micrasterias by the $18 \mathrm{~S}$ rDNA and $\operatorname{trn} G^{U C C}$ intron sequences.

Etymology - The specific epithet was chosen in honour to Pierre Compère, one of the leading scientists in desmid research.

\section{Phylogenetic analysis}

The Bayesian unrooted phylogenetic tree was based on 2469 characters of the $18 \mathrm{~S}$ rDNA gene and $\operatorname{trn} G^{U C C}$ intron sequences (fig. 3). The monophyletic $\mathrm{C}$ clade of the genus Micrasterias (originally defined by Škaloud et al. 2011) was strongly supported by the phylogenetic analyses (1.00/100/100). The clade encompassed five species forming two lineages. The species pair of $M$. brachyptera and M. compereana $(1.00 / 81 / 99)$ was separated from a group of three species, $M$. torreyi and a pair of $M$. rotata and $M$. fimbriata $(0.96 / 74 / 94)$. Neustupa et al. (2011) showed that the $\operatorname{trn} G^{U C C}$ intron sequences were identical within the lineage representing six strains of M. compereana, as well as within ten strains of M. fimbriata sensu stricto. Conversely, the $\operatorname{trn} G^{U C C}$ intron sequences between these taxa differed by 11 nucleotides (electronic appendix 2). The $\operatorname{trn} G^{U C C}$ intron sequences of the strains, morphologically corresponding to the type of $M$. fimbriata Ralfs (Ralfs 1848: plate VIII, fig. 2), were identical with the sequence FR731997 (Neustupa et al. 2011). These 


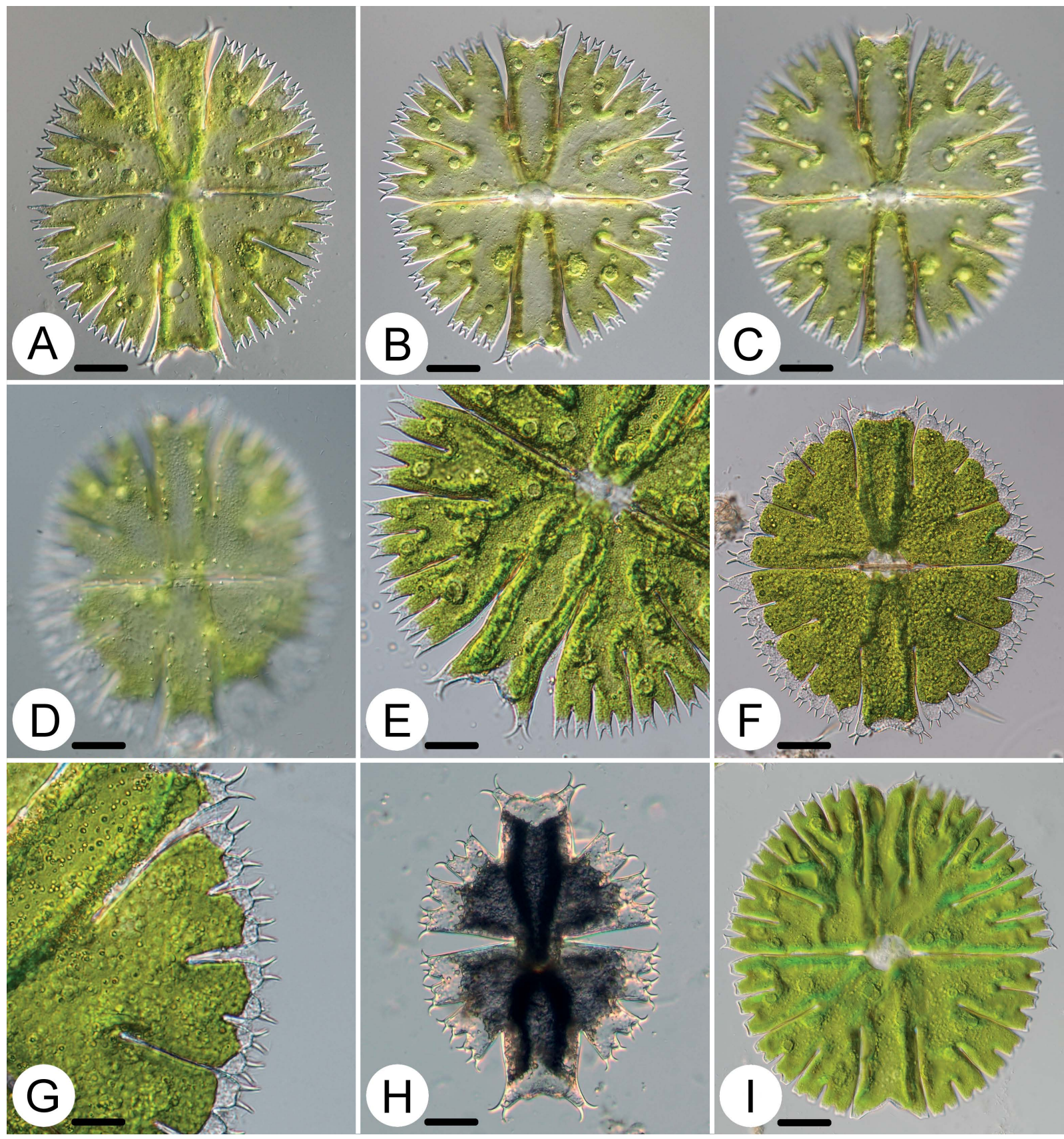

Figure 1 - Micrographs of Micrasterias compereana and related taxa: A-E, Micrasterias compereana; F-G, Micrasterias fimbriata; H, Micrasterias brachyptera; I, Micrasterias rotata. A-D, F \& H-I, front view; C-D, focus on surface spines; E \& G, details of terminal lobules. Scale bars represent $30 \mu \mathrm{m}(\mathrm{A}-\mathrm{D}, \mathrm{F} \& \mathrm{I}), 20 \mu \mathrm{m}(\mathrm{E}), 15 \mu \mathrm{m}(\mathrm{G})$ or $35 \mu \mathrm{m}(\mathrm{H})$.

strains also invariably possessed rounded terminal lobules ending with abruptly protruding spines (fimbriae) (figs $1 \mathrm{~F}-\mathrm{G}$ \& 2C-D), instead of gradually tapering projections, typical for M. compereana (fig. 1E). In addition, they differed from M. compereana also by shallower incisions. The main incisions between the polar and lateral lobes of $M$. fimbriata usually did not exceed one half of the semicell length. Neustupa et al. (2011) also illustrated unambiguous separation of $M$. fimbriata from populations attributable to M. compereana by quantitative geometric morphometrics of the cell shape.

\section{Morphological characteristics}

Morphological characteristics of $M$. compereana did not correspond with any of the previously described infraspecific taxa of M. fimbriata. Next to the nominate variety, Krieger (1939) recognized four additional varieties of $M$. fimbriata. However, most of these infraspecific taxa were only rarely recorded and their separate taxonomic status is highly uncertain. Two of the varieties, M. fimbriata var. brasiliensis W.Krieger and M. fimbriata var. elephanta Wolle, are poorly known, and clearly differ from the nominate variety, as well as from M. compereana, by considerably larger cells, ex- 


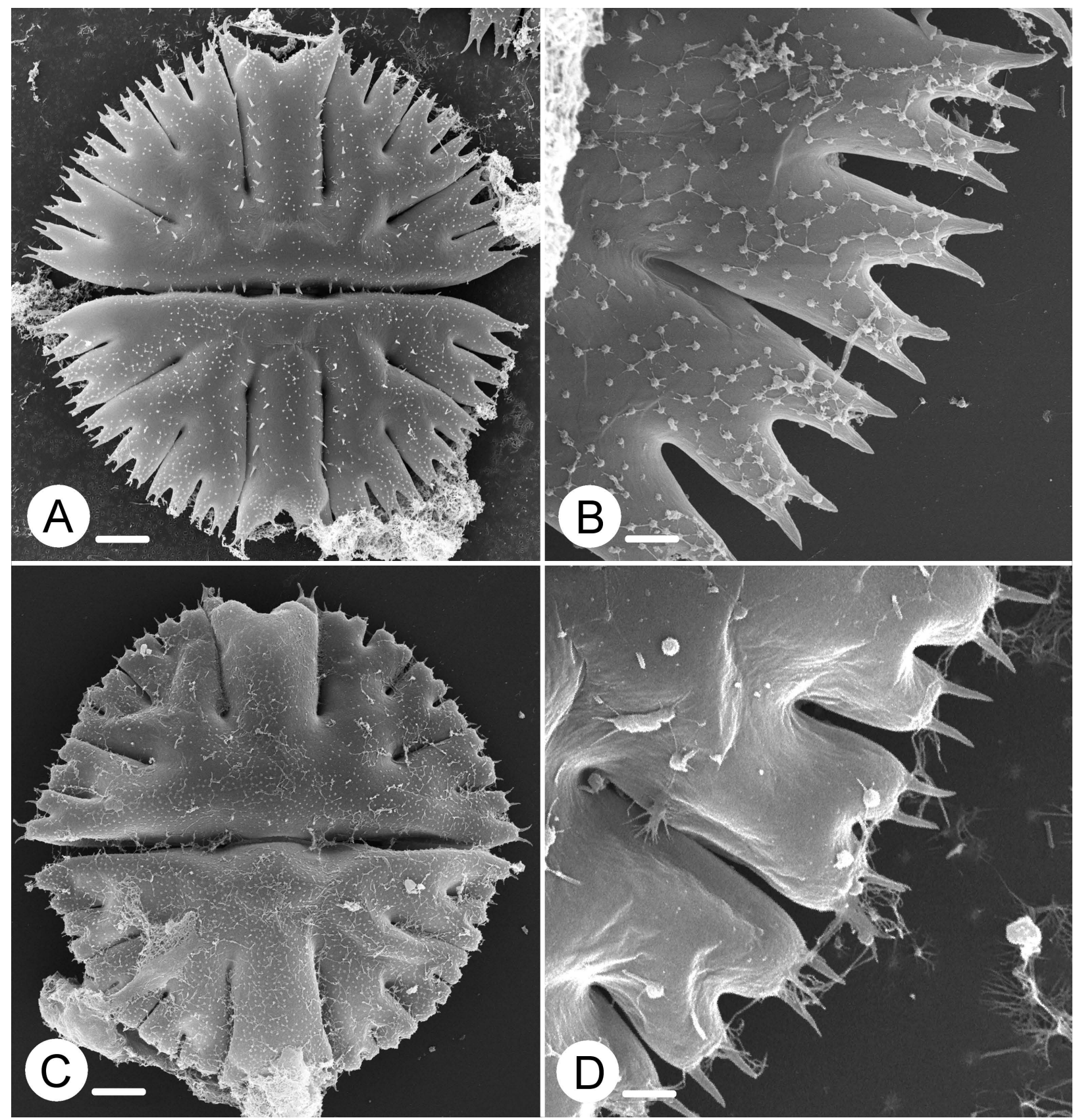

Figure 2 - SEM micrographs of Micrasterias compereana and Micrasterias fimbriata: A-B, Micrasterias compereana; C-D, Micrasterias fimbriata. A \& C, front view; B \& D, focus on terminal lobules. Scale bars represent $30 \mu \mathrm{m}$ (A \& C) or $10 \mu \mathrm{m}$ (B \& D).

ceeding $300 \mu \mathrm{m}$ in length and width. Micrasterias fimbriata var. obtusiloba Raciborski is more similar to the nominate variety, especially by the shape of the terminal lobules, and probably only represents an anomalous form (Rủžička 1981). Micrasterias fimbriata var. spinosa Bisset is the only infraspecific taxon of $M$. fimbriata that was also recognized by Růžička (1981). It differs from the nominate variety by rows of spines along sinus and major incisions. This character can be found both in M. compereana, as well as on the cells of $M$. fimbriata. However, the iconotype of $M$. fimbriata var. spinosa (Roy \& Bisset 1893: plate IV, fig. 3) clearly belongs to $M$. fimbriata by the shape of the terminal lobules.
Therefore, M. fimbriata var. spinosa cannot be related to $M$. compereana.

The strains and natural populations of $M$. compereana also differ from other closely related species of the clades $\mathrm{B}$ and $\mathrm{C}$ of the genus Micrasterias (table 1). These clear-cut differences in cell shape and size typically allow instantaneous discrimination between cells of individual taxa, including $M$. brachyptera (fig. 1H), the closest phylogenetic relative of M. compereana, as well as M. rotata (fig. 1I). In addition, $M$. compereana and other taxa of the clade $\mathrm{C}$ proved to be phylogenetically unrelated to other morphologically vaguely similar Micrasterias taxa, such as M. radiosa 


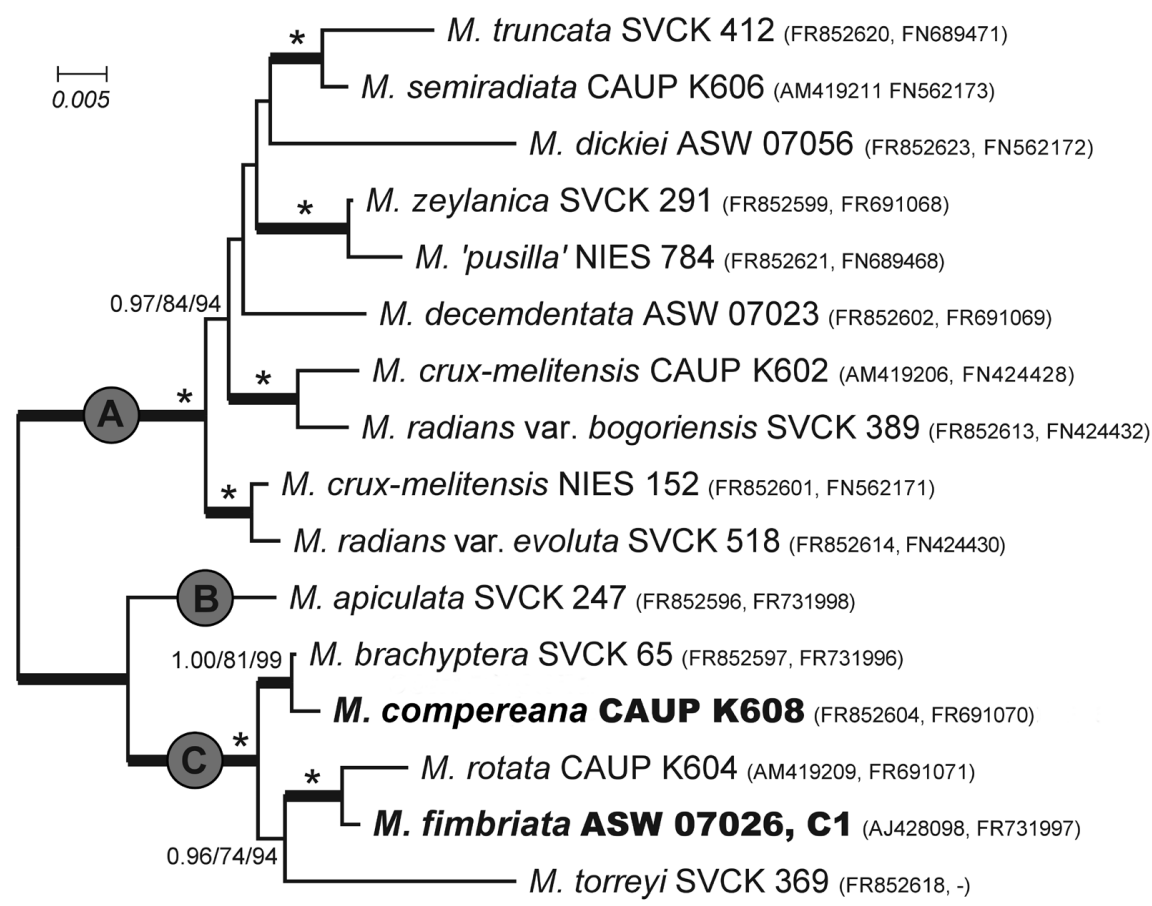

Figure 3 - Phylogenetic tree based on the Bayesian analysis of the combined SSU rDNA and trn $G^{U C C}$ intron sequences, showing the position of Micrasterias compereana, M. fimbriata and their relatives. Values at the nodes indicate statistical support estimated by MrBayes posterior node probability (left), maximum likelihood bootstrap (in the middle) and maximum parsimony bootstrap (right). Full statistical support $(1.00 / 100 / 100)$ is marked with an asterisk. Thick branches represent nodes receiving the highest PP support (1.00). Species affiliation to three Micrasterias clades (A, B, C) established by Škaloud et al. (2011) is indicated. Scale bar represents the estimated number of substitutions per site.

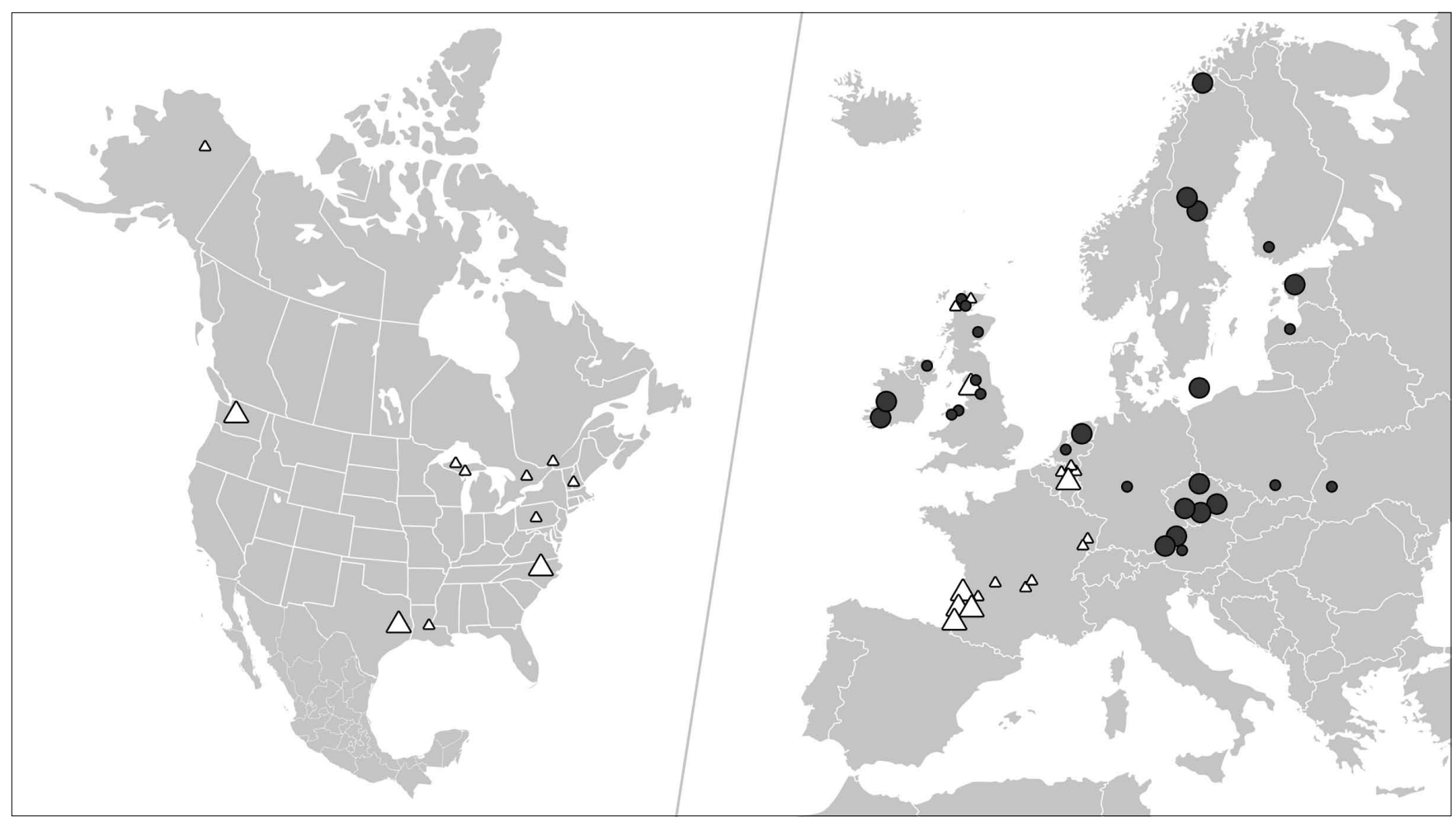

Figure 4 - Records of Micrasterias compereana $(\triangle)$ and Micrasterias fimbriata $(\bullet)$ in Europe and North America. Smaller symbols correspond to published literature records (for a complete list see Neustupa et al. 2011), larger symbols relate to our own observations of natural populations or strains. 
Table 1 - Morphological differences among selected Micrasterias taxa.

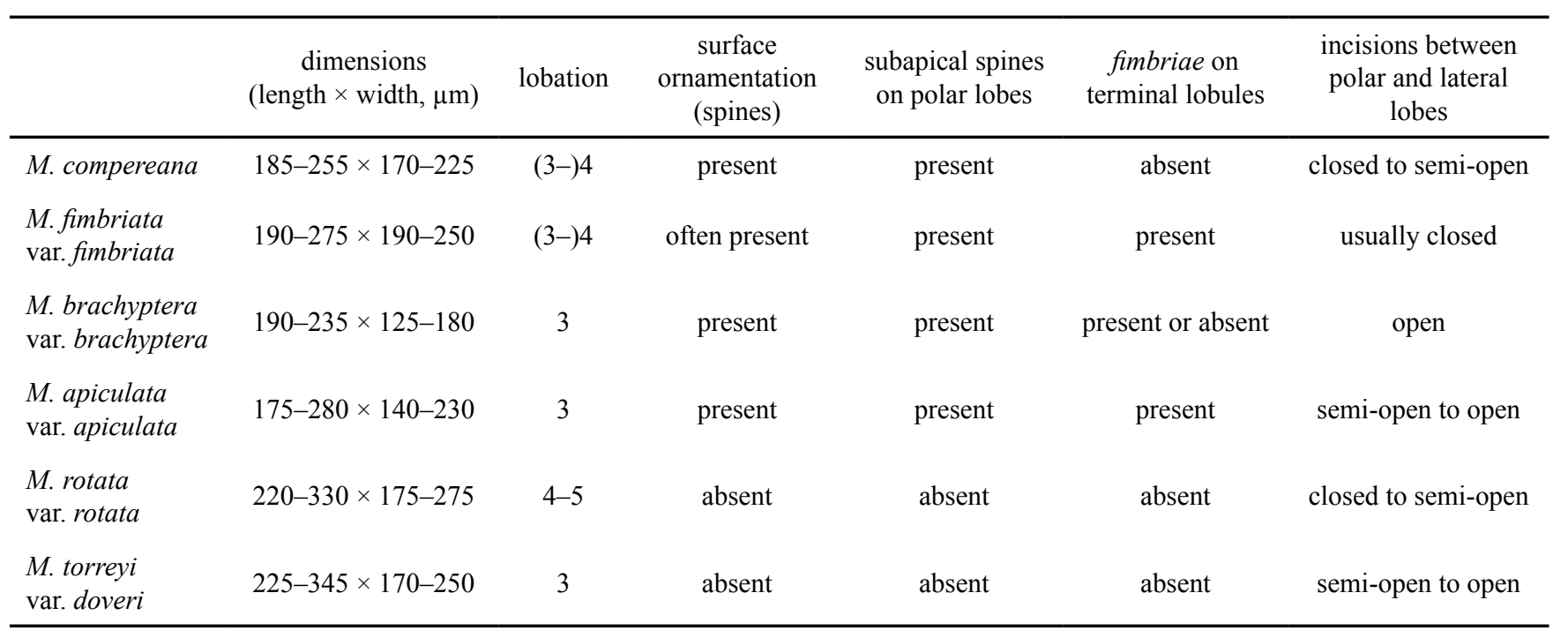

and $M$. papillifera, which belong to the well-supported clade $\mathrm{G}$ sensu Škaloud et al. (2011). In conclusion, M. compereana represents a well-defined species, both on the basis of molecular and morphological data. However, the overall cell shape with multiple lobes and lobules, typical for the large Micrasterias taxa, coupled with the presence of conspicuous subapical spines on the apex of the polar lobe, led earlier authors to identification of the natural populations of this species as $M$. fimbriata. Earlier recognition of the separate taxonomic status of $M$. compereana and $M$. fimbriata was also complicated by their largely vicariant geographic distribution. The analysis of the natural samples, strains from the culture collections, as well as the numerous published records of the traditional $M$. fimbriata (for a complete list see Neustupa et al. 2011) illustrated that the North American specimens and published records (e.g. Croasdale 1956, Förster 1972, Smith 1924) invariably corresponded to $M$. compereana (fig. 4). As far as could be traced, $M$. fimbriata sensu stricto has not been encountered on this continent. M. compereana also relatively frequently occurs and has been repeatedly reported (as $M$. fimbriata) from various localities in the western Europe, including France, Belgium, southern parts of the Netherlands and Britain (e.g. Comère 1901, Kouwets 1987, Desmids in the Netherlands 2003). Its typical habitat is in oligotrophic bogs at low $\mathrm{pH}$ values, as well as in phytobenthos of acidic lakes. Conversely, M. fimbriata sensu stricto is more frequently encountered in mesotrophic, slightly acidic fens. Interestingly, we did not find any specimens or published illustration of $M$. fimbriata sensu stricto from the above mentioned parts of the continental Europe. The British Isles seem to be the only region where $M$. compereana occurs sympatrically with $M$. fimbriata sensu stricto (including Ralfs' (1848) type locality of $M$. fimbriata near Dolgellau, Wales). Besides the localities in Britain and Ireland, M. fimbriata sensu stricto occurs in continental Europe and (possibly) Asia. In Europe it has never been found south of the Alps and west of the Rhine river. In central and eastern Europe, it is a rare species of mesotrophic fens or bogs (Lenzenweger 1996, St'astný 2010). It is more common in Scandinavia, but it is rarely encountered in higher cell quantities. Traditionally defined M. fimbriata has also been reported from northern Asia (Kossinskaya 1960, Medvedeva 2001), but we did not find any original figures that could be used for a tentative evaluation of its taxonomic identity.

Micrasterias compereana undoubtedly belongs to one of the most conspicuous microalgae inhabiting moderately acidic freshwater wetlands. It can be relatively easily recognized and identified by light microscopy. Therefore, we believe that its separation from $M$. fimbriata and formal taxonomic description, presented in this paper, will lead to additional records of this peculiar desmid species from various European and American localities. This could significantly increase our present knowledge of its geographic distribution. It should also be noted that in microalgae the observed eastern distribution limit of $M$. compereana in Europe possibly represents one of the rare examples of a restricted distribution area that is in want of any obvious underlying ecological factor or geographic barrier. Therefore, any additional records of $M$. compereana from continental Europe should be regarded most valuable.

\section{SUPPLEMENTARY DATA}

Supplementary data are available at Plant Ecology and Evolution, Supplementary Data Site (http://www.ingentaconnect. com/content/botbel/plecevo.supp-data), and consist of: (1) natural samples and strains of Micrasterias compereana and $M$. fimbriata investigated in this study (pdf); and (2) sequence alignment used for the phylogenetic analyses (FAS file).

\section{ACKNOWLEDGEMENTS}

The authors thank Peter F.M. Coesel, Emma Goodyer, Frans Kouwets and Koos J. Meesters for their invaluable advice on the distribution of Micrasterias at various European localities, as well as for their kind provision of fixed natural samples or microphotographs. We thank the anonymous re- 
viewer for his/her critique that led us to the improvements of the manuscript.

\section{REFERENCES}

Andersen R.A., Berges J.A., Harrison P.J., Watanabe M.M. (2005) Recipes for freshwater and seawater media. In: Andersen R.A. (ed.) Algal culturing techniques: 429-538. San Diego, Elsevier Academic Press.

Coesel P.F.M., Meesters J. (2007) Desmids of the Lowlands. Zeist, KNNV Publishing.

Comère J. (1901) Les Desmidiées de France. Paris, Paul Klincksieck.

Croasdale H. (1956) Freshwater algae of Alaska I. Some desmids from the interior. Part 2: Actinotaenium, Micrasterias and Cosmarium. Transactions of the American Microscopical Society 75: $1-70$.

Desmids in the Netherlands (2003) Desmid of the month, July 2003. Micrasterias fimbriata [online]. Available from http:// www.desmids.nl/maand/english/micrasterias_fimbriata.html [accessed 14 Feb. 2014].

Förster K. (1972) Desmidieen aus dem Südosten der Vereinigten Staaten von America. Nova Hedwigia 23: 515-644.

Gontcharov A.A. (2008) Phylogeny and classification of Zygnematophyceae (Streptophyta): current state of affairs. Fottea 8: 87-104.

Gontcharov A.A., Melkonian M. (2011) A study of conflict between molecular phylogeny and taxonomy in the Desmidiaceae (Streptophyta, Viridiplantae): Analyses of $291 \mathrm{rbcL}$ sequences. Protist 162: 253-267. http://dx.doi.org/10.1016/j.protis.2010.08.003

Hall J.D., Karol K.G., McCourt R.M., Delwiche C.F. (2008) Phylogeny of the conjugating green algae based on chloroplast and mitochondrial nucleotide sequence data. Journal of Phycology 44: 467-477. http://dx.doi.org/10.1111/j.1529-8817.2008.00485.x

Kossinskaya E.K. (1960) Flora Sporovych Rastenii SSSR. Tom V. Desmidievye vodorosli. Moscow, Izdatelstvo Akademii Nauk SSSR.

Kouwets F. (1987) Desmids from the Auvergne (France). Hydrobiologia 146: 193-263. http://dx.doi.org/10.1007/BF00016347

Krieger W. (1939) Die Desmidiaceen. Kryptogamen Flora Bd. 13, Teil 2. Leipzig, Akademisches Verlag.

Kumar S., Dudley J., Nei M., Tamura K. (2008) MEGA: a biologist-centric software for evolutionary analysis of DNA and protein sequences. Briefings in Bioinformatics 9:299-306. http:// dx.doi.org/10.1093/bib/bbn017

Lenzenweger R. (1996) Desmidiaceenflora von Österreich, Teil 1. Stuttgart, Gebrüder Borntraeger Verlagsbuchhandlung.

Medvedeva L.A. (2001) Biodiversity of aquatic algal communities in the Sikhote-Alin biosphere reserve (Russia). Cryptogamie Algologie 22: 65-100. http://dx.doi.org/10.1016/S01811568(00)01050-3

Nemjová K., Neustupa J., Št’astný J., Škaloud P., Veselá J. (2011) Species concept and morphological differentiation of strains traditionally assigned to Micrasterias truncata. Phycological Research 59: 208-220. http://dx.doi.org/10.1111/j.14401835.2011.00619.x

Neustupa J., Škaloud P., Št'astný J. (2010) The molecular phylogenetic and geometric morphometric evaluation of Micrasterias crux-melitensis / M. radians species complex. Journal of Phycology 46: 703-714. http://dx.do1.org/10.1111/j.15298817.2010.00863.x

Neustupa J., Št’astný J., Nemjová K., Mazalová P., Goodyer E., Poulíčková A., Skkaloud P. (2011) A novel, combined approach to assessing species delimitation and biogeography within the well-known desmid species Micrasterias fimbriata and M. rotata (Desmidiales, Steptophyta). Hydrobiologia 667: 223-239. http://dx.doi.org/10.1007/s10750-011-0650-3

Prescott G.W., Croasdale H.T., Vinyard W.C. (1977) A Synopsis of North American Desmids, Part II. Desmidiaceae: Placodermae, Sect. 2. Lincoln, University of Nebraska Press.

Ralfs J. (1848) The British Desmidieae. London, Reeve, Benham \& Reeve.

Ronquist F., Huelsenbeck J.P. (2003) MRBAYES 3: Bayesian phylogenetic inference under mixed models. Bioinformatics 19:1572-1574. http://dx.doi.org/10.1093/bioinformatics/btg180

Roy J., Bisset K.P. (1893) On Scottish Desmidieae I. The Annals of Scottish Natural History 5: 106-111.

Růžička J. (1981) Die Desmidiaceen Mitteleuropas, Band 1, 2. Lieferung. Stuttgart, E. Schweizerbartsche Verlagsbuchhandlung.

Smith G.M. (1924) Phytoplankton of the inland lakes of Wisconsin. Part II. Desmidiaceae. Bulletin - Wisconsin Geological and Natural History Survey 57: 1-221.

Škaloud P., Nemjová K., Veselá J., Černá K., Neustupa J. (2011) A multilocus phylogeny of the desmid genus Micrasterias (Streptophyta): evidence for the accelerated rate of morphological evolution in protists. Molecular Phylogenetics and Evolution 61: 933-943. http://dx.doi.org/10.1016/j.ympev.2011.08.018

Št’astný J. (2010) Desmids (Conjugatophyceae, Viridiplantae) from the Czech Republic; new and rare taxa, distribution, ecology. Fottea 10: 1-74.

Št’astný J., Škaloud P., Langenbach D., Nemjová K., Neustupa J. (2013) Polyphasic evaluation of Xanthidium antilopaeum and Xanthidium cristatum (Zygnematophyceae, Streptophyta) species complex. Journal of Phycology 49: 401-416. http://dx.doi. org/10.1111/jpy.12051

Swofford D.L. (2002) PAUP*. Phylogenetic Analysis Using Parsimony (*and Other Methods). Version 4. Sunderland, Massachusetts, Sinauer Associates.

Zwickl D.J. (2006) Genetic algorithm approaches for the phylogenetic analysis of large biological sequence datasets under the maximum likelihood criterion. $\mathrm{PhD}$ thesis, University of Texas at Austin, Austin, USA.

Manuscript received 12 Mar. 2014; accepted in revised version 10 Jul. 2014.

Communicating Editor: Bart Van de Vijver. 